\section{Commentary: Standing upon the shoulders of giants}

\author{
Laura Seese, MD, ${ }^{\mathrm{a}}$ and Danny Chu, $\mathrm{MD}^{\mathrm{a}, \mathrm{b}}$
}

The landscape of cardiothoracic (CT) surgery has rapidly changed over the past decade with evolving transcatheter, minimally invasive, and robotic technologies. ${ }^{1-3} \mathrm{CT}$ surgery trainees now must master both the classic surgical repertoire and the expanding modern operative approaches while simultaneously learning the nuances of patient care and balancing clerical, academic, and bureaucratic demands. To further compound the situation, these endeavors must all occur in less hours compared with the prior generations of trainees. The bulk of instruction is focused on the technical aspects such that trainees can emerge as proficient CT surgeons. However, as the presidential addresses of the leaders of the American Association of Thoracic Surgery have heralded, there is much more to a CT surgeon than being a "glorified technician." The consummate CT surgeon must also have the qualities of humility, leadership, an appreciation of their support system outside of the hospital, and humanistic qualities that bind them to their patients. These traits must be cultivated during training and refined throughout our careers.

In the current issue of the Journal, Han and colleagues ${ }^{4}$ present the second part of their series for young surgeons, Timeless Lessons From Leaders in Cardiothoracic Surgery, which focuses on the past president's thoughts on character development. With components on leadership, cultivating a legacy through trainee education, maintaining humanism in patient care, finding purpose in your profession, and prioritizing family, this succinct compilation of the most poignant guidance from leaders in our field should be on every young surgeon's reading list. Key highlights include an emphasis on the importance of our interactions with others where Dr Smith recalls that "without a question,

From the a Department of Cardiothoracic Surgery, University of Pittsburgh School of Medicine, Pittsburgh, Pa; and ${ }^{\mathrm{b}}$ University of Pittsburgh Medical Center Heart \& Vascular Institute, Pittsburgh, Pa.

Disclosures: Authors have nothing to disclose with regard to commercial support.

Received for publication Feb 19, 2020; accepted for publication Feb 19, 2020; available ahead of print March 9, 2020.

Address for reprints: Danny Chu, MD, University of Pittsburgh Medical Center Heart \& Vascular Institute, 200 Lothrop St, Suite C-700, Pittsburgh, PA 15213 (E-mail: chud@upmc.edu).

J Thorac Cardiovasc Surg 2020;160:998-9

$0022-5223 / \$ 36.00$

Copyright (c) 2020 by The American Association for Thoracic Surgery

https://doi.org/10.1016/j.jtcvs.2020.02.090

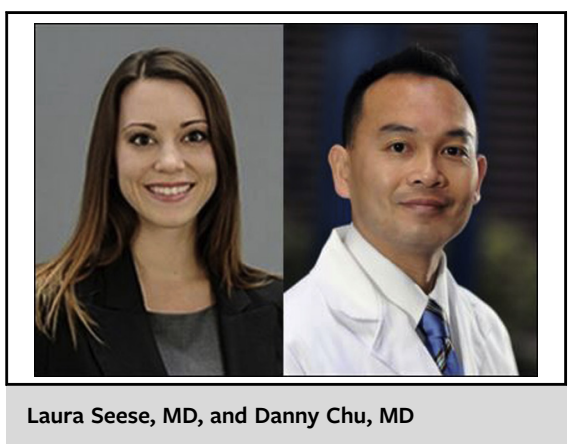

CENTRAL MESSAGE

In addition to technical skills, young surgeons must simultaneously cultivate leadership and humanistic qualities. Advice from leaders in the field helps inspire and refine these essential traits.

our character and our qualities are more important than what we do with our hands." ${ }^{4}$ Additionally, comments on the fundamental elements of a leader are equally inspiring, with Dr Lytle stating that "leadership is something you emanate... somewhat with your brain... but mostly with your heart." 4

After presenting the character development advice from the past presidents, the authors distilled the overall messages into important reflections for young surgeons. Although many of these assertions are excellent mantras to emphasize during training, their reflections on worklife balance sparked contemplation. The authors suggest that the reality is that "young surgeons are developing as both CT surgeons and adults." ${ }^{4}$ However, many CT trainees are already "adults" with spouses, mortgages, and families when starting training and the attempts to prioritize both realms, professional and personal, originate early. Work-life balance is a popular term for this nirvana of equality between work and family, yet finding consistent balance is uncommon. This is evidenced by the tensions and guilt expressed by the past presidents who admirably strove to prioritize both their profession and their families. Family is an essential aspect of the human experience. However, rather than suggesting that "balance" can be attained with committed effort, it may be more helpful to suggest that a young CT surgeon can be equally dedicated to their family and their patients, but that this may often resemble a pendulum rather than a balanced scale. 


\section{References}

1. Mack MJ, Leon MB, Thourani VH, Makkar R, Kodali SK, Russo M, et al. Transcatheter aortic-valve replacement with a balloon-expandable valve in low-risk patients. N Engl J Med. 2019;380:1695-705.

2. Okusanya OT, Hess NR, Luketich JD, Sarkaria IS. Technique of robotic assisted minimally invasive esophagectomy (RAMIE). J Vis Surg. 2017;3:116.
3. Coyan G, Wei LM, Althouse A, Roberts HG, Schauble D, Murashita T, et al. Robotic mitral valve operations by experienced surgeons are cost-neutral and durable at 1 year. J Thorac Cardiovasc Surg. 2018;156:1040-7.

4. Han JJ, Kelly JJ, Patrick WL, Iyengar A, Atkins M, Pietras C. Timeless lesson from the past and present leaders of cardiothoracic surgery part 2: character development. J Thorac Cardiovasc Surg. 2020;160:991-7.
See Article page 991.

\section{Commentary: Back to the future: Lessons from our residents}

\author{
Virginia R. Litle, MD
}

In Part I of the "Timeless Lessons From the Past and Present Leaders of Cardiothoracic Surgery," Han and colleagues ${ }^{1}$ reflected on 4 decades of presidential words of wisdom with regard to professional accomplishments including surgical excellence, mentorship, and scholarship. In Part II, the resident authors reflect on the character development aspects and categorize the talks into those of humanism, balance, leadership, and the future. ${ }^{2}$ Essentially all leaders discussed Leadership and the Future, whereas the Humanism and Balance content varied over time. As a mid- to senior-career academic surgeon and married mother of 3, I will provide a female reflection of the valuable attributes of gratitude, well-being, and coaching to create a strong leader.

\section{HUMANISM: GRATITUDE AT THE CORE}

Echoing past leaders, we as healers are most grateful for the privilege of caring for others. That is the seed from which our professional success must grow. Dr Maddaus, in his recent raw and personal account of a life-changing event, outlined the science behind gratitude and relief of stress. ${ }^{3,4}$ Dr Rusch, in her American College of Surgeons Presidential Address, thanked those who provided guidance to her along her exemplary path to surgical leadership. ${ }^{5}$ The

From the Division of Thoracic Surgery, Department of Surgery, Boston University School of Medicine, Boston, Mass

Disclosures: Author has nothing to disclose with regard to commercial support.

Received for publication March 7, 2020; revisions received March 7, 2020; accepted for publication March 9, 2020; available ahead of print March 25, 2020.

Address for reprints: Virginia R. Litle, MD, Division of Thoracic Surgery, Department of Surgery, Boston University, 88 East Newton St, Collamore 7380, Boston,

MA 02118 (E-mail: Virginia.litle@bmc.org).

J Thorac Cardiovasc Surg 2020;160:999-1000

0022-5223/ $\$ 36.00$

Copyright (c) 2020 by The American Association for Thoracic Surgery

https://doi.org/10.1016/j.jtcvs.2020.03.048
Check for updates

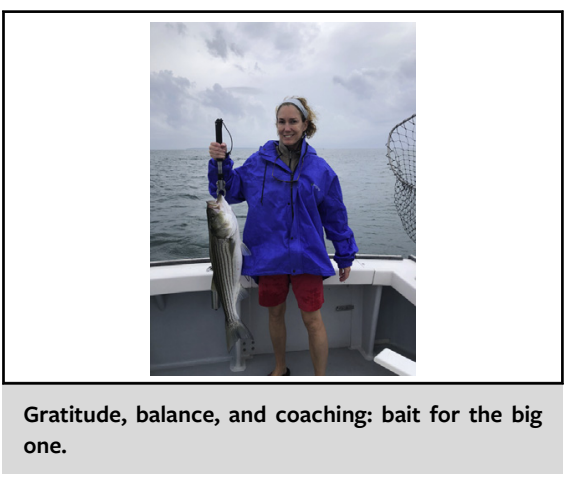

CENTRAL MESSAGE

The evolution of humanism, balance, and well-being in the words of past, present, and future leaders of cardiothoracic surgery.

times are a changin' and we are grateful for the support of our leaders in the \#HeforShe movement. Dr Patterson, in particular in his presidential address, appreciated that with a nadir in the number of residents pursuing cardiothoracic surgery, the other half of the talent pool (ie, women) must be attracted to our field. ${ }^{6}$ Speaking on behalf of Women in Thoracic Surgery, we are grateful for all the men who have attended our receptions and supported us on \#SoMe. The times have changed indeed.

\section{BALANCE: HEAL THYSELF}

The increasingly anachronistic term "work-life balance" is transitioning into terms of wellness and valuing self-care. "We can only take care of patients as humane surgeons if we protect our own humanity," write the resident authors. ${ }^{2}$ Regarding time management, Saunders, in the Harvard Business Review, suggested we create schedules that reflect our values: "1: Get clear what is important... 2: Define why they are important... 3: Fuse your priorities with your schedule." It may be possible in this era of evolving 